\title{
Congenital Absence of the Cystic Duct: A Rare but Significant Anomaly
}

\author{
Sachin Patil ${ }^{1,2}$, Sudhir Jain ${ }^{2}$, Ramachandra C. M. Kaza', Ronald S. Chamberlain ${ }^{1,3,4^{*}}$ \\ ${ }^{1}$ Department of Surgery, Saint Barnabas Medical Center, Livingston, USA \\ ${ }^{2}$ Department of Surgery, Maulana Azad Medical College, New Delhi, India \\ ${ }^{3}$ Saint George's University School of Medicine, St. George, Grenada \\ ${ }^{4}$ Department of Surgery, University of Medicine and Dentistry of New Jersey, Newark, USA \\ Email: *DChamberlain@barnabashealth.org
}

Received November 29, 2012; revised December 30, 2012; accepted January 8, 2013

Copyright (C) 2013 Sachin Patil et al. This is an open access article distributed under the Creative Commons Attribution License, which permits unrestricted use, distribution, and reproduction in any medium, provided the original work is properly cited.

\begin{abstract}
Cholecystectomy is the most common digestive tract surgery performed worldwide and injury to the bile duct leads to both acute and chronic sequelae. The incidence of bile duct injury is increased in the presence of severe inflammation and is compounded by congenital abnormalities of the biliary tract. Congenitally absent cystic duct is one such rare anomaly with significant surgical implications. So far only nine clear cases of congenitally absent cystic duct have been reported. In this report we describe two additional cases of a congenitally absent cystic duct and provide a comprehensive discussion of the clinical significance, and appropriate surgical management of this anomaly.
\end{abstract}

Keywords: Cystic Duct; Congenital Absence; Absent Cystic Duct

\section{Introduction}

Cholecystectomy is the most common digestive tract surgery performed worldwide with over 600,000 cholecystectomies performed yearly in the United States [1,2]. Injury to the bile duct is a dreaded complication of cholecystectomy which leads to both acute and chronic sequelae. The incidence of bile duct injury is increased in the presence of severe inflammation and is compounded by the presence of congenital abnormalities of the biliary tract [3]. The extrahepatic biliary system displays the highest number of anatomical variations of any site in the body [4], accounting for $8 \%$ to $14 \%$ in autopsy series and $47.2 \%$ in biliary tract surgery [5]. Congenital absence of the cystic duct is one such anomaly and although rare, it is surgically important. Hayes et al. reported two cases (0.01\%) of a congenitally absent cystic duct among 189 extrahepatic biliary anomalies identified in 400 patients [4]. Lamah et al. noted only three cases $(0.25 \%)$ of a congenitally absent cystic duct among 12 extrahepatic biliary anomalies in 2125 patients [6]. In this report, we describe two additional cases of a congenitally absent cystic duct and provide a discussion of the clinical significance and appropriate surgical management of this anomaly.

\footnotetext{
"Corresponding author.
}

\section{Case Reports}

Case 1

A 28-year-old healthy male presented with acute right upper quadrant pain (RUQ) and vomiting for 12 hours. Vital signs revealed a pulse of $108 / \mathrm{min}$, blood pressure of $100 / 70 \mathrm{mmHg}$ and respiratory rate of $24 / \mathrm{min}$. The abdomen was mildly distended with tenderness and RUQ voluntary guarding. Laboratory evaluation was remarkable for a direct bilirubin of $2 \mathrm{mg} / \mathrm{dl}$ (reference range: 0 0.4 ), alkaline phosphatase of $320 \mathrm{IU} / \mathrm{L}$ (reference range: 30 - 290), amylase of $1460 \mathrm{IU} / \mathrm{L}$ (reference range: 30 330) and lipase of $1050 \mathrm{IU} / \mathrm{L}$ (reference range: 20 - 90). Abdominal ultrasound demonstrated cholelithiasis with choledocholithiasis. The common bile duct (CBD) was dilated to $9.5 \mathrm{~mm}$ with a $6.5 \mathrm{~mm}$ calculus. Endoscopic retrograde cholangiopancreatography (ERCP) with papillotomy and stone extraction was performed. The patient was scheduled for a subsequent laparoscopic cholecystectomy. Three weeks later he represented with similar complaints and with an elevated amylase of $1650 \mathrm{IU} / \mathrm{L}$ and lipase of $950 \mathrm{IU} / \mathrm{L}$. A magnetic resonance cholangiopancreatography (MRCP) revealed a contracted gallbladder with cholelithiasis, choledocholithiasis and intrahepatic biliary ductal dilatation. An ERCP with stone extraction, followed by an open retrograde cholecystectomy 
was performed. Operative findings were remarkable for a gallbladder (GB) directly attached to the common hepatic duct with complete absence of the cystic duct. There were no adhesions noted between the GB and surrounding structures and there was no stone impaction in GB neck. CBD exploration revealed no additional intraluminal calculi. The gallbladder was resected leaving a 5 $\mathrm{mm}$ segment of GB adherent to the CBD which was closed with interrupted absorbable suture. Post-operative recovery was uneventful.

\section{Case 2}

A 30-year-old healthy male presented with acute RUQ and emesis for 12 hours. Vital signs revealed a pulse of $110 / \mathrm{min}$, a blood pressure of 90/70 $\mathrm{mmHg}$ and a respiratory rate of $22 / \mathrm{min}$. The patient exhibited mild scleral icterus. The abdomen was mildly distended with voluntary guarding and RUQ tenderness. Pertinent laboratory values revealed a WBC count of 16,000/cumm (reference range: 4000 - 11,000), a direct bilirubin of $3 \mathrm{mg} / \mathrm{dl}$ (reference range: $0-0.4$ ), an alkaline phosphatase of 280 IU/L (reference range: 30 - 290), amylase of $1630 \mathrm{IU} / \mathrm{L}$ (reference range: 30 - 330) and lipase of 1200 IU/L (reference range: 20 - 90). Abdominal ultrasound identified multiple gallstones, a $10 \mathrm{~mm}$ CBD and no CBD stones. Magnetic resonance cholangiopancreatography (MRCP) identified only cholelithiasis without CBD stones. The GB was contracted and appeared to end directly into the CBD. The distal body and the tail of the pancreas were edematous with peripancreatic stranding consistent with acute pancreatitis. The patient recovered after conservative management and was scheduled for subsequent cholecystectomy. Five weeks later he represented with recurrent gallstone pancreatitis. Imaging studies again demonstrated a $10 \mathrm{~mm}$ CBD without calculi. Contrast enhanced computed tomography (CECT) revealed the distal body and tail of the pancreas had ill-defined contours but normal enhancement. There was no evidence of necrotizing pancreatitis and the main pancreatic duct was not dilated. After conservative management the patient was taken for an elective open cholecystectomy. The GB was found to abruptly enter the CBD without narrowing. CBD exploration revealed no intraluminal calculi. The GB was resected leaving a $5 \mathrm{~mm}$ segment of GB adherent to the CBD which was closed with interrupted absorbable suture. Post-operative recovery was uneventful.

\section{Materials and Methods}

A comprehensive English and non-English search for all articles pertinent to an absent cystic duct was conducted using PubMed, a search engine provided by the US National Library of Medicine and the National Institutes of Health. Key words searched included: "absent cystic duct" "cystic duct", "congenital absent cystic duct" and "congenitally anomalies of bile ducts". Cases identified were analyzed in regards to age and gender of patients, symptoms at presentation, surgical outcome and intraoperative findings. Patients with recurrent jaundice, recurrent pancreatitis, and intra-operative findings of direct attachment of the GB into the CHD and without gallstone impaction in the GB neck or CBD/CHD were considered to have a congenital absent cystic duct [5]. Patients with dense pericholecystic adhesions and/or gallstone impaction were considered to have acquired absence of cystic duct.

\section{Results}

A total of 11 cases, including the two cases presented here, of congenitally absent cystic duct have been reported (Table 1). Although 18 cases of cystic duct anomalies have been reported as congenital absent cystic duct, critical analysis of these cases reveal that 9 of the 18 reported cases had signs of acquired absent cystic duct which included dense pericholecystic adhesions and/or gallstone impaction. Five additional cases have been alluded to in other publications, but are not included in this report due to lack of pertinent patient information or intraoperative findings [4,6]. Case 2 is included in our analysis despite the presence of an impacted stone at the GB/common duct junction, since the patient did present with recurrent episodes of jaundice and only minimal adhesions between the GB and CHD were noted. The median age among the 11 patients was 49 years, with a M:F ratio of $1: 2.3$. Seven of nine previously reported patients had recurring symptoms prior to surgery, lasting on average 14.7 years (range 2 to 25 years). A retrograde cholecystectomy approach was utilized in 8 cases (cases 2 - 5, 7, 9 - 11) and one patient was treated with cholecystostomy (case 8). Two patients had an antegrade cholecystectomy (cases 1 and 6) and in both cases the common bile duct was mistaken as the cystic duct and was ligated and divided. During one retrograde cholecystectomy the surgeon electively resected a segment of common bile duct along with the GB, followed by primary repair (case 4).

\section{Discussion}

Cystic duct anatomy was first described by Francis Glisson in 1654 [7]. The cystic duct arises from the neck of gallbladder, runs caudal and parallel to the common hepatic duct (CHD), and joins the CHD to form CBD [8]. The mean cystic duct length is $30 \mathrm{~mm}$ (range $4 \mathrm{~mm}$ to 65 $\mathrm{mm}$ ) and the diameter ranges from 3 to $9 \mathrm{~mm}$ [9]. The cystic duct is considered part of the extrahepatic biliary apparatus which includes the right and left hepatic ducts, the CHD and the CBD. The cystic duct is lined by simple columnar epithelium and is surrounded by an inconspicuous layer of smooth muscle [10]. There are 5 to 12 cresentic mucosal folds in the cystic duct, similar to 
Table 1. Published cases of congenitally absent cystic duct.

\begin{tabular}{|c|c|c|c|c|}
\hline $\begin{array}{l}\text { Case } \\
\text { No. }\end{array}$ & Author, year & $\begin{array}{c}\text { Age }(Y) \text {, } \\
\text { gender }\end{array}$ & Symptoms, duration & Surgical approach and intraoperative findings \\
\hline 1. & $\begin{array}{l}\text { Walton et al., } \\
1921 \text { [25] }\end{array}$ & 38, NM & $\mathrm{H} / \mathrm{o}$ gallstones $\times 5$ years. & $\begin{array}{l}\text { Antegrade cholecystectomy with accidental complete transaction of } \\
\text { right and left hepatic ducts and CBD. Primary anastomosis of } \\
\text { transected ducts. } \\
\text { Dissection of specimen revealed three separate openings for right and } \\
\text { left hepatic ducts and CBD in the region of the neck of GB. }\end{array}$ \\
\hline 2. & $\begin{array}{l}\text { Stetten et al., } \\
1923 \text { [26] }\end{array}$ & 48, F & $\begin{array}{l}\text { H/o recurrent dyspepsia } \times 12 \\
\text { years. } \\
\text { Acute cholecystitis, jaundice } \\
\times 5 \text { days. }\end{array}$ & $\begin{array}{l}\text { Retrograde cholecystectomy with cuff of GB around CBD and primary } \\
\text { continuous closure. } \\
\text { GB directly attached to CHD, with a large stone impacted at the } \\
\text { junction. }\end{array}$ \\
\hline 3. & $\begin{array}{l}\text { Walker et al., } \\
1927 \text { [27] }\end{array}$ & $52, \mathrm{M}$ & $\begin{array}{c}\text { Intermittent jaundice and } \\
\text { epigastric pain }(3 \text { attacks }) \times 2 \\
\text { years. } \\
\text { Dyspepsia } \times 1 \text { year. }\end{array}$ & $\begin{array}{l}\text { Retrograde cholecystostomy with extraction of solitary stone with } \\
\text { T-tube placement. } \\
\text { GB directly attached to the CHD with separate openings for CHD and } \\
\text { CBD. } \\
\text { Pancreatitis. }\end{array}$ \\
\hline 4. & $\begin{array}{l}\text { Niemer et al., } \\
1942 \text { [28] }\end{array}$ & $51, \mathrm{~F}$ & $\begin{array}{l}\text { Flatulent dyspepsia } \times 20 \\
\text { years. } \\
\text { Recurrent jaundice }(3 \\
\text { attacks }) \times 9 \text { months. }\end{array}$ & $\begin{array}{l}\text { Retrograde cholecystectomy, anastomosis of CHD and CBD with } \\
\text { T-tube placement. } \\
\text { Two separate openings for the CHD and CBD in the neck of GB. }\end{array}$ \\
\hline 5. & $\begin{array}{l}\text { Rabinovitch et } \\
\text { al., } 1956 \text { [29] }\end{array}$ & 58, F & $\begin{array}{c}\text { Colicky RUQ pain } \times \text { several } \\
\text { years. }\end{array}$ & $\begin{array}{l}\text { Retrograde cholecystectomy with a cuff of GB around hepatic duct. } \\
\text { GB directly attached to the left hepatic duct, right hepatic duct inserted } \\
\text { into neck of GB. }\end{array}$ \\
\hline 6. & I anoer et al & $51, \mathrm{~F}$ & $\begin{array}{l}\text { Dyspepsia x } 25 \text { years. } \\
\text { Recurrent colicky pain and } \\
\text { painful mass in the RUQ } \times 3 \\
\text { months. }\end{array}$ & $\begin{array}{l}\text { Antegrade cholecystectomy, accidental transaction of CBD and CHD, } \\
\text { primary anastomosis of CBD and CHD with T-tube placement. } \\
\text { Liver enlarged and congested. GB enlarged, thick walled. } \\
\text { GB directly attached to the CHD with a small aperture between them. }\end{array}$ \\
\hline 7. & $1963[30]$ & 49, F & $\begin{array}{l}\text { Fat intolerance and biliary } \\
\text { colic } \times 24 \text { years. } \\
\text { Two episodes of acute } \\
\text { cholecystitis and jaundice. }\end{array}$ & $\begin{array}{l}\text { Retrograde cholecystectomy and primary closure of common duct with } \\
\text { T-tube placement. } \\
\text { GB, right and left hepatic ducts were opening into a cloaca-like } \\
\text { structure which continued downwards as CBD. Multiple calculi in } \\
\text { CBD. }\end{array}$ \\
\hline 8. & $\begin{array}{l}\text { Sperling et al., } \\
\quad 1964 \text { [31] }\end{array}$ & 67, F & $\begin{array}{l}\text { Acute cholecystitis, RUQ } \\
\text { distress } \times 10 \text { days }\end{array}$ & $\begin{array}{l}\text { Retrograde cholecystostomy with extraction of stones and T-tube } \\
\text { placement. } \\
\text { GB directly attached to the common duct with two separate openings } \\
\text { for hepatic duct and CBD. }\end{array}$ \\
\hline 9. & $\begin{array}{l}\text { Adam et al., } \\
1966[5]\end{array}$ & 43, F & $\begin{array}{l}\text { RUQ pain and vomiting } \times 5 \\
\text { years. }\end{array}$ & $\begin{array}{l}\text { Retrograde cholecystectomy, with primary repair of the CBD. } \\
\text { GB was directly attached to the common duct with wide opening of } 1.2 \\
\mathrm{~cm} \text { in length and } 0.4 \mathrm{~cm} \text { in width. }\end{array}$ \\
\hline 10. & & 28, M & $\begin{array}{l}\text { Recurrent RUQ pain, } \\
\text { jaundice }(2 \text { attacks }) \times 1 \\
\text { month. }\end{array}$ & $\begin{array}{l}\text { Retrograde cholecystectomy, with primary closure of CBD with GB } \\
\text { cuff. } \\
\text { GB directly attached to the common duct. }\end{array}$ \\
\hline 11. & Current cases & 30, M & $\begin{array}{l}\text { Recurrent RUQ pain, } \\
\text { jaundice }(2 \text { attacks }) \times 2 \\
\text { months. }\end{array}$ & $\begin{array}{l}\text { Retrograde cholecystectomy, with primary closure of CBD with GB } \\
\text { cuff. } \\
\text { GB directly attached to the common duct. }\end{array}$ \\
\hline
\end{tabular}

Abbreviations: No., number; Y, years; NM; not mentioned, H/o, history of; CBD, common bile duct; GB, gallbladder; CHD, common hepatic duct; RUQ, right upper quadrant pain.

those found in the neck of gallbladder [8]. Although these folds are referred to as valves of Heister, they have no valvular function [11].

Embryologically, the gallbladder and cystic duct develop from the caudal part of the hepatic diverticulum, which is a ventral outgrowth from the distal foregut whose maturation is influenced by fibroblast growth factor (FGFs) secreted from the fetal heart [12]. Failed development of the proximal part of the gallbladder diverticulum results in agenesis of the cystic duct [5]. Com- plete agenesis of the gallbladder and cystic duct is a well known entity [13-15], but an isolated congenitally absent cystic duct is rare and only 11 cases have been reported (including two reported here) (Table 1). Other congenital variations of the cystic duct are seen in $18 \%$ to $23 \%$ of individuals [16], and relate to its entry point and mode of union with the CHD (Figure 1).

Cystic duct anatomy may also be altered in pathologic conditions resulting in progressive dilatation of the cystic duct due to the passage of gallstones [17], or complete 


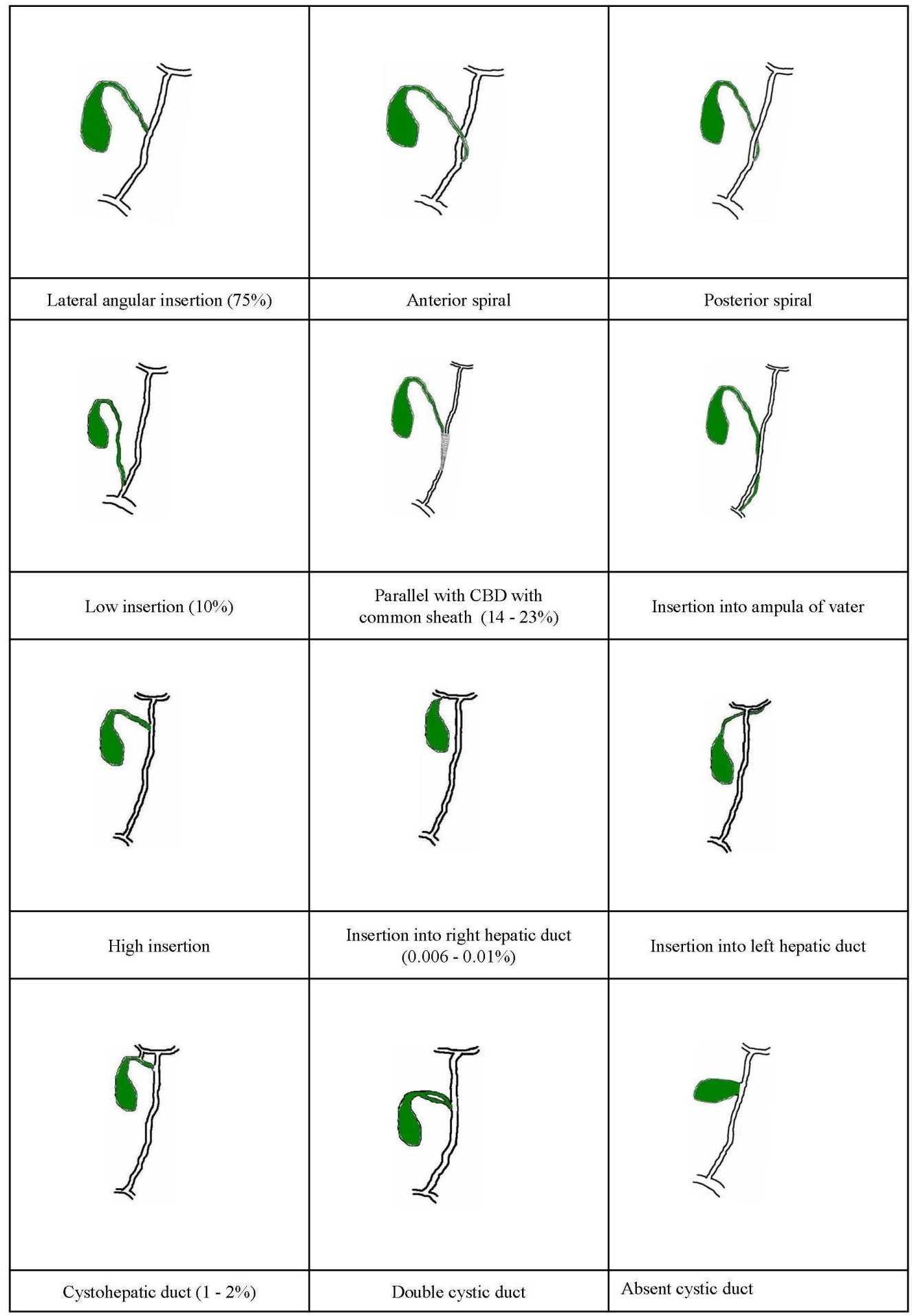

Figure 1. Common congenital anomalies of cystic duct.

destruction of the cystic duct as in Mirizzi syndrome [18]. In cases of congenitally absent cystic duct the gallbladder is directly attached to the common duct with a wide mouth [7], permitting free flow of gallstones into the CBD which may result in recurrent pain, jaundice and gallstone pancreatitis. Acquired cystic duct pathlogy or
Mirizzi syndrome, rarely if ever present with gallstone pancreatitis [19-24]. Additional differences between congenital and acquired absence of the cystic duct are summarized in Table 2.

When congenital absence of the cystic duct is identified pre-operatively, open cholecystectomy is typically 
Table 2. Differences between congenitally and acquired absent cystic duct.

\begin{tabular}{|c|c|c|}
\hline \multirow[t]{2}{*}{ Parameter } & \multicolumn{2}{|c|}{ Absent Cystic Duct } \\
\hline & Congenital & Acquired \\
\hline Cause & $\begin{array}{l}\text { Proximal part of gallbladder diverticulum fails to } \\
\text { develop }\end{array}$ & Gallstone impaction with inflammation, fibrosis and scarring \\
\hline Initial Presentation & $\begin{array}{l}\text { Jaundice } \\
\text { Acute Pancreatitis }\end{array}$ & $\begin{array}{l}\text { Biliary colic } \\
\text { Acute cholecystitis }\end{array}$ \\
\hline Histopathology & $\begin{array}{l}\text { Gallbladder with all the three layers: } \\
\text { Mucosa } \\
\text { Lamina propria and } \\
\text { Muscularis propria } \\
\text { Absent muscularis mucosa and } \\
\text { submucosa }\end{array}$ & $\begin{array}{l}\text { Cystic duct remnant with three layers: } \\
\text { Mucosa } \\
\text { Lamina propria and } \\
\text { connective tissue layer with inflammatory cells } \\
\text { and fibrosis } \\
\text { Absent muscularis mucosa, submucosa and } \\
\text { muscularis propria }\end{array}$ \\
\hline Radiological findings & $\begin{array}{l}\text { Collapsed gallbladder with wide mouth, attached } \\
\text { directly to the CHD. } \\
\text { No signs of inflammation. }\end{array}$ & $\begin{array}{l}\text { Distended gallbladder. Gallstones may be found impacted at } \\
\text { the cystic duct remnant } \\
\text { Chronic inflammation }\end{array}$ \\
\hline Complications & $\begin{array}{l}\text { Obstructive jaundice } \\
\text { Recurrent pancreatitis at short intervals }\end{array}$ & $\begin{array}{l}\text { Obstructive jaundice } \\
\text { Pancreatitis } \\
\text { Mirizzi’s syndrome }\end{array}$ \\
\hline
\end{tabular}

performed. A small cuff of the GB can be left near the CBD and closed primarily and a T-tube is inserted through a separate choledochotomy site [5]. If the gall bladder tissue is too inflamed with extensive destruction of the common hepatic duct, Roux-en-Y hepaticojejunostomy may be required. If the condition is encountered laparoscopically, conversion to open cholecystectomy with intraoperative cholangiography is strongly recommended, particularly if the anatomy is ambiguous. Though laparoscopic management is feasible, it requires precise knowledge of the anomaly and sufficient surgical skills.

\section{Conclusions}

Congenital anomalies of the extrahepatic bile ducts are common. Short or aberrant cystic duct entry or union with the CHD is routinely encountered, especially in the presence of severe pericholecystic inflammation. However, a congenitally absence of the cystic duct is a rare entity with severe surgical implications. Patients with recurrent episodes of gallstone pancreatitis separated by brief intervals should raise the suspicion of a congenitally absent cystic duct and lead the surgeon to consider open cholecystectomy or at least assess their skills prior to laparoscopic cholecystectomy. Knowledge of this anomaly and its mode of presentation and preferred surgical approach should help avoid inadvertent biliary injuries and the complex biliary procedures which may be required to fix them.

The authors acknowledge the help and support of the staff in Medical Records Division at Maulana Azad Medical Center.

\section{REFERENCES}

[1] S. B. Archer, D. W. Brown, C. D. Smith, G. D. Branum and J. G. Hunter, "Bile Duct Injury during Laparoscopic Cholecystectomy: Results of a National Survey,” Annals of Surgery, Vol. 234, No. 4, 2001, pp. 549-558. doi:10.1097/00000658-200110000-00014

[2] N. F. Fiore, G. Ledniczky, E. A. Wiebke, et al., “An Analysis of Perioperative Cholangiography in One Thousand Laparoscopic Cholecystectomies," Surgery, Vol. 122, No. 4, 1997, pp. 817-821. doi:10.1016/S0039-6060(97)90092-1

[3] C. Williams and A. M. Williams, "Abnormalities of Bile Ducts,” Annals of Surgery, Vol. 141, No. 5, 1955, pp. 598-605.

[4] M. A. Hayes, I. S. Goldenberg and C. C. Bishop, "The Developmental Basis for Bile Duct Anomalies,” Surgery, Gynecology \& Obstetrics, Vol. 107, No. 4, 1958, pp. 447456.

[5] Y. Adam and W. Metcalf, "Absence of the Cystic Duct: A Case Report, the Embryology and a Review of the Literature," Annals of Surgery, Vol. 164, No. 6, 1966, pp. 1056-1058. doi:10.1097/00000658-196612000-00016

[6] M. Lamah and G. H. Dickson, "Congenital Anatomical Abnormalities of the Extrahepatic Biliary Duct: A Personal Audit," Surgical and Radiologic Anatomy, Vol. 21, No. 5, 1999, pp. 325-327. doi:10.1007/BF01631333

[7] W. Hamilton, "The History of Medicine, Surgery and Anatomy [II],” London, 1831, p. 169.

[8] S. Standring, "Hepatobiliary System: Extrahepatic Biliary Tree,” In: S. Standring, Ed., Gray's Anatomy; The Anatomical Basis of Clinical Practice, 39th Edition, Elsevier Churchill Livingstone, Philadelphia, 2004, p. 1228.

[9] D. A. Moosman and F. A. Collier, "Prevention of Traumatic Injury to the Bile Ducts; A Study of the Structures of the Cystohepatic Angle Encountered in Cholecystec- 
tomy and Supraduodenal Choledochostomy," American Journal of Surgery, Vol. 82, No. 1, 1951, pp. 132-143. doi:10.1016/0002-9610(51)90309-1

[10] L. C. Junqueira, "Organs Associated With Digestive Tract: Biliary Tract,” In: L. C. Junqueira, Ed., Basic Histology; A Text and Atlas, 11th Edition, McGraw-Hill, New York, 2005, pp. 336-337.

[11] T. R Gadacz, “Anatomy, Embryology, Anomalies and Physiology of the Gallbladder and Biliary Ducts," In: G. D. Zuidema and C. J. Yeo, Eds., Shackelford's Surgery of the Alimentary Tract, 5th Edition, W.B. Saunders Company, Philadelphia, 2002, pp. 143-157.

[12] K. L. Moore, “The Digestive System,” In: K. L. Moore, Eds., The Developing Embryo; Clinically Oriented Embryology, 8th Edition, Saunders, Philadelphia, 2007, pp. 219-220.

[13] V. Fiaschetti, G. Calabrese, S. Viarani, G. Bazzocchi and G. Simonetti, "Gallbladder Agenesis and Cystic Duct Absence in an Adult Patient Diagnosed by Magnetic Resonance Cholangiography: Report of a Case and Review of the Literature," Case Reports in Medicine, Vol. 2009, 2009, Article ID: 674768.

[14] F. M. De, M. Calabrese, S. Quinto, et al., "Congenital Anomalies and Variations of the Bile and Pancreatic Ducts: Magnetic Resonance Cholangiopancreatography Findings, Epidemiology and Clinical Significance,” Radiologia Medica, Vol. 113, No. 6, 2008, pp. 841-859. doi:10.1007/s11547-008-0298-X

[15] J. Yu, M. A. Turner, A. S. Fulcher and R. A. Halvorsen, "Congenital Anomalies and Normal Variants of the Pancreaticobiliary Tract and the Pancreas in Adults: Part 1, Biliary Tract,” American Journal of Roentgenology, Vol. 187, No. 6, 2006, pp. 1536-1543. doi:10.2214/AJR.05.0772

[16] M. A. Turner and A. S. Fulcher, "The Cystic Duct: Normal Anatomy and Disease Processes," Radiographics, Vol. 21, No. 1, 2001, pp. 3-22.

[17] M. Castelain, C. Grimaldi, A. G. Harris, et al., "Relationship between Cystic Duct Diameter and the Presence of Cholelithiasis,” Digestive Diseases and Sciences, Vol. 38, No. 12, 1993, pp. 2220-2224. doi:10.1007/BF01299899

[18] E. C. Lai and W. Y. Lau, "Mirizzi Syndrome: History, Present and Future Development," ANZ Journal of Surgery, Vol. 76, No. 4, 2006, pp. 251-257. doi:10.1111/j.1445-2197.2006.03690.x

[19] A. Csendes, J. C. Diaz, P. Burdiles, F. Maluenda and O. Nava, "Mirizzi Syndrome and Cholecystobiliary Fistula:
A Unifying Classification,” British Journal of Surgery, Vol. 76, No. 11, 1989, pp. 1139-1143.

doi:10.1002/bjs.1800761110

[20] M. Ibrarullah, R. Saxena, S. S. Sikora, V. K. Kapoor, V. A. Saraswat and S. P. Kaushik, "Mirizzi's Syndrome: Identification and Management Strategy,” Australian and New Zealand Journal of Surgery, Vol. 63, No. 10, 1993, pp. 802-806. doi:10.1111/j.1445-2197.1993.tb00344.X

[21] S. T. Fan, W. Y. Lau, M. J. Lee, K. P. Wong and K. K. Wong, "Cholecystohepaticodochal Fistula: The Value of Pre-Operative Recognition,” British Journal of Surgery, Vol. 72, No. 9, 1985, pp. 743-744. doi:10.1002/bjs.1800720925

[22] A. W. Yip, W. C. Chow, J. Chan and K. H. Lam, "Mirizzi Syndrome with Cholecystocholedochal Fistula: Preoperative Diagnosis and Management,” Surgery, Vol. 111, No. 3, 1992, pp. 335-338.

[23] X. D. He, H. S. Liu, C. J. Zheng, Z. H. Zhang and J. X. Zhang, "Diagnosis and Treatment of the Mirizzi Syndrome," Chinese Medical Sciences Jourmal, Vol. 14, No. 4, 1999, pp. 246-248.

[24] E. J. Lubbers, "Mirizzi Syndrome," World Journal of Surgery, Vol. 7, No. 6, 1983, pp. 780-785. doi:10.1007/BF01655221

[25] A. J. Walton, "Reconstruction of Common Bile Duct," British Journal of Surgery, Vol. 9, No. 34, 1921, pp. 169178. doi:10.1002/bjs.1800093402

[26] D. Stetten, “Anomalous Relations of Cystic Duct or Gall Bladder to Hepatic Duct," Surgical Clinics of North America, Vol. 3, 1923, pp. 539-548.

[27] I. J. Walker, “Anomaly of the Bile Ducts,” The Boston Medical and Surgical Journal, Vol. 196, 1927, pp. 733744. doi:10.1056/NEJM192705051961807

[28] O. W. Niemer, "Report of Case of Unusual Anomaly of Bile Ducts in Adult with Obstructive Jaundice," Surgery, Vol. 12, 1942, pp. 584-590.

[29] J. Rabinovitch, P. Rabinovitch and H. J. Zisk, "Rare Anomalies of the Extrahepatic Bile Ducts," Annals of Surgery, Vol. 144, No. 1, 1956, pp. 93-98. doi:10.1097/00000658-195607000-00014

[30] B. Langer and F. G. Pearson, “Absent Cystic Duct: An Unusual Hazard during Cholecystectomy,” Canadian Journal of Surgery, Vol. 6, 1963, pp. 29-32.

[31] M. J. Sperling, “Absence of the Cystic Duct,” Archives of Surgery, Vol. 88, No. 6, 1964, pp. 1077-1078. doi:10.1001/archsurg.1964.01310240173030 